\title{
Proposals and Territorial Concerns of the Geography Students Involved in the Project We Propose! 2019/20
}

\author{
Ricardo COSCURÃ̃ ${ }^{1}$ \\ University of Lisbon, Lisbon, PORTUGAL
}

\author{
Sérgio CLAUDINO ${ }^{2}$ \\ University of Lisbon, Lisbon, PORTUGAL
}

\begin{abstract}
${ }^{1}$ Corresponding author: PHD Student, under Grant: SFRH/BD/139986/2018 by FCT - Fundação para a Ciência e a Tecnologia, I.P.; University of Lisbon, Centre of Geographical Studies (CEG), Institute of Geography and Spatial Planning (IGOT), Lisbon, PORTUGAL. rcoscurao [at] edu.ulisboa.pt. ORCID: 0000-0003-0814-0166

${ }^{2}$ Prof. Dr.; University of Lisbon, Centre of Geographical Studies (CEG), Institute of Geography and Spatial Planning (IGOT), Wuppertal, PORTUGAL. sergio [at] edu.ulisboa.pt. ORCID: 0000-0001-6987-4812
\end{abstract}

\begin{abstract}
Project We Propose! was created in Portugal in 2011/12 at the Institute of Geography and Spatial Planning of the University of Lisbon ("Instituto de Geografia e Ordenamento do Território da Universidade de Lisboa") to challenge young people to identify local problems and present concrete proposals to solve them. In addition to Portugal, the project has spread throughout six other countries. This article focuses on analyzing the content of the proposals submitted by Portuguese students within the scope of this Project, for the academic year 2019/2020. Despite the suspension of face-to-face classes due to COVID-19, 323 proposals were submitted, being developed by a total of 1360 students from 43 schools and with the guidance of 58 teachers. On average, the working groups comprised approximately 4 elements. Adopting the proper procedures of content analysis techniques, enabled a set of categories and subcategories to be defined and also allowed categorization of each of the submitted proposals at two levels: the main fundamental concern and the type of proposal. Cultural and recreational concerns were the most frequent, however, the students' most valued type of proposal involved some form of intervention in the public space. Diversity was a dominant factor in the results obtained, thus reinforcing the versatility of the Project We Propose!, which is never detached from the promotion of a geographical education committed to education for citizenship.
\end{abstract}

\section{Keywords}

Project We Propose!; Territorial Concerns; Content Analysis; Geographical Education; Citizenship Education

To cite this article: Coscurão, R.; Claudino, S. (2021). Proposals and territorial concerns of the geography students involved in the project we propose! 2019/20. Review of International Geographical Education (RIGEO), 11(3), pp-pp. doi: 10.33403rigeo.799251 
Project We Propose!: Citizenship and Innovation in Geographical Education (The Project) was created in 2011/12, within the scope of the Institute of Geography and Spatial Planning of the University of Lisbon. The Project tries to combine the call for the participation of the population, right from the youngest, in decision-making on the territory (Bazolli, 2017) with the renewal of a geographic education that wants to be increasingly committed to the aspirations of the local community, meeting from the perspectives of Geography that value social justice and environmental balance (Souto \& Claudino, 2019). Resulting from the partnership between the university and the primary and secondary schools, thousands of students from Portugal and other countries and continents (Spain, Mozambique, Brazil, Peru, Colombia and Mexico) have been observing their community with a critical stance. They identify relevant social and territorial issues, such as: the requalification of a square, in order to increase its use by the population; the creation of a cycle path in the city to promote sustainable mobility; promoting leisure activities for young people or building a virtual museum of local traditions. Pupils carry out field work on their matters, listening to the population about their proposals, creating proposals for solving such problems as well as sharing them with the community, in a perspective of territorial citizenship (Claudino, 2019). It is the Geography teaching experimental project (although open to the participation of students and teachers from other areas) that currently holds the utmost internationalization. In Portugal, despite the suspension of classroom activities due to COVID-19, in 2019/2020, once again, hundreds of students presented their proposals for solving problems of their community.

The versatility associated with the implementation of Project We Propose! allows finding various types of realities in the elaborated proposals. There are the two fundamental questions or topics this Project seeks to answer, based on the total proposals submitted by students from Portuguese schools in the academic year 2019/2020:

- Which were the main concerns and issues underlying the proposals developed by the students?

- Which types of proposal were more privileged?

The paper starts with a short theoretical contextualization centered on the geographical education contribution to citizenship education, and the role of Project We Propose! Interconnecting these two fundamental areas. The paper continues with the general characterization of the total proposals considered. Such characterization, in turn, gives rise to an analysis focused on the content of the proposals, never losing sight of the two fundamental matters that guide this work.

\section{Theoretical Framework}

\section{Project We Propose! Intersecting Geographical Education and Citizenship Education}

When citizen participation is a requirement of democratic societies (Ivorra Catalá, García Ferrandis \& Moreno Latorre, 2020), the relationship between Geography and citizenship education has been one of the most privileged research topics by those who 
write about geographical education. The knowledge and skills gained by students who study Geography have been considered important contributions to the development of such capabilities in terms citizen education. As backed by Palacios and Barahona (2019), geographical education promotes rigor in the formulation of thought and in processing information which contributes to the development of responsible civic attitudes. The training of young reflective citizens implies they understand how the world works due to their understanding of geographical processes which favour reflection, decision-making and participation in society (Machon \& Walkington 2000); therefore allowing students to explore and understand the world in which they live so that they can act on it (Martins, 2017). Basically, citizenship can be considered a sense of self-attachment to places (Schmidt, 2011). Geographic knowledge thus increases the potential of young people, as conscious and informed citizens (Lambert, 2017), and the main concepts mobilized by Geography can even contribute to a new type of citizens, with an enhanced understanding of the world they live (Shin \& Bednarz, 2019). We can therefore conclude that geographical education provides a territorial dimension to education for citizenship, leading us to a spatial citizenship, a concept often used in works of this nature, or to a territorial citizenship, as supported by Claudino (2018).

In the contribution of geographical education to education for citizenship, we can find the importance of a multiscale reasoning. It is necessary to provide students with opportunities to investigate at local, national, and global levels, establishing links between these different analysis levels and implementing civic actions in these spatial areas (Hilburn \& Maguth, 2015).

The conducts, concepts and skills developed during the learning process of Geography are fundamental for any citizens who participate consciously and actively in solving problems within their locality, community, region, country, or even those at worldwide scale (Ferreira, Alexandre \& Miranda, 2001, p. 163).

As previously shown, the first level of analysis of a multi-scale process to identify problems and look for solutions is held locally, which can facilitate identification of problems with territorial expression due to the proximity to students' daily lives. It is precisely within this context that we find Project We Propose!, which arises from the need (in programmatic terms) and the importance of implementing a Case Study, by students of 16-17 years old, in the scope of the Geography subject, as well as well as the "concern to promote the participation of people in the decisions on spatial planning" (Claudino, 2015, p. 15). Thus, we speak of a Project aimed at identifying local, social, and environmental problems with territorial expression, giving Geography classes "social and citizen skills and promoting experiences that will serve them as a model for citizen action" (Souto \& Claudino, 2019, p. 9). It is necessary to "bring students out to the streets, carry out fieldwork on the citizens' common problems" (Claudino, 2015, p. 15), which demonstrates the role of the Project We Propose! at the intersection of geographical education and education for citizenship.

\section{The Project We Propose! and the 2030 Agenda for Sustainable Development}

"The 2030 Agenda for Sustainable Development was launched in 2015 to end poverty and set the world on a path of peace, prosperity and opportunity for all on a healthy planet" 
(United Nations, 2020, p. 2). As part of this global strategy, 17 Sustainable Development Goals were defined. These Goals "demand nothing short of a transformation of the financial, economic and political systems that govern our societies today to guarantee the human rights of all. They require immense political will and ambitious action by all stakeholders" (United Nations, 2020, p. 2). This global development strategy implies the mobilization of everyone, including the youngest, who are encouraged to take an active attitude towards the problems that affect the world, at different scales. We can say that Project We Propose!, encourages students to develop proposals and think about solving problems with territorial expression, in the place where they live. To do so makes a contribution to the promotion of the 2030 Agenda for Sustainable Development and to the 17 Sustainable Development Goals, particularly for objective 4.7 (Education) which tells us

By 2030, ensure that all learners acquire the knowledge and skills needed to promote sustainable development, including, among others, through education for sustainable development and sustainable lifestyles, human rights, gender equality, promotion of a culture of peace and non-violence, global citizenship and appreciation of cultural diversity and of culture's contribution to sustainable development (United Nations, 2015, p. 21).

Likewise, by frequently providing the development of proposals aimed at problems in urban space, Project We Propose! establishes a relationship with objective 11.7 (Cities): "by 2030, provide universal access to safe, inclusive and accessible, green and public spaces, in particular for women and children, older persons and persons with disabilities" (United Nations, 2015, p. 26)". Through the relationship with these and other Sustainable Development Goals, within the scope of the 2030 Agenda for Sustainable Development, the potential of the Project We Propose! in terms of promoting students' territorial citizenship, never moves away from a sustainable development perspective.

\section{Methodology}

\section{Brief Characterization of the Total Proposals Submitted}

In Portugal, in the academic year 2019/2020, Project We Propose! received 323 submission of proposals, involving a total of 1360 students and 58 teachers from 43 schools. Before the national suspension of school activities due to the pandemic, on March 16, 2020, it was estimated that the number of projects drawn up by students was about 420 . This was a reduction of around $28 \%$ in the submission of projects. According to the rules of The Project, all participating students present their proposals, however, each school can elect a set of proposals which they consider to be winners and which are then submitted for consideration by a national jury. The total number of proposals to be submitted as winners varies according to the total number of students participating in each school. Of the 323 proposals submitted in 2019/2020, 94 represented the submissions of the winning projects in each school. It should be noted that these totals represent the proposals developed by secondary school students. In addition to those, some proposals were submitted by younger students, from elementary education. For exceptional situations, with their own specificities, these proposals are not included in this analysis, so as to prevent a possible bias in the results thereof. 
Coscurão, R.; Claudino, S. (2021). Proposals and territorial concerns of the geography students...

The average number of students per workgroup (Table 1) was approximately four students. Likewise, despite registering groups composed of one to eight students, $43 \%$ of the proposals were submitted by 4 element groups, being this the most frequent situation. This reality leads us to the specific guidelines associated with implementation of The Project.

Table 1

Proposals Submitted, According To the Number of Elements per Group

\begin{tabular}{|l|l|l|}
\hline Total of student & 1360 \\
\hline Students per group (average) & 4,2 \\
\hline No. of elements per group & $\begin{array}{l}\text { Proposals } \\
\text { submitted }\end{array}$ & $\%$ \\
\hline 1 & 5 & $2 \%$ \\
\hline 2 & 12 & $4 \%$ \\
\hline 3 & 41 & $13 \%$ \\
\hline 4 & 140 & $43 \%$ \\
\hline 5 & 105 & $33 \%$ \\
\hline 6 & 18 & $6 \%$ \\
\hline 7 & 1 & $0 \%$ \\
\hline 8 & 1 & $0 \%$ \\
\hline Total of proposals & 323 & $100 \%$ \\
\hline
\end{tabular}

When we carry out the same type of analysis, considering the nature of the submissions (Table 2), we find similar trends, both in the case of submissions and in terms of submissions of the winning projects at the school level. The average number of elements per group continues to be around four students, which is the number of elements in most situations.

Table 2

Proposals Submitted According To the Type of Submission and the Number of Elements per Group

\begin{tabular}{|l|l|l|l|l|}
\cline { 2 - 5 } \multicolumn{1}{c|}{} & \multicolumn{2}{l|}{ Submissions } & \multicolumn{2}{l|}{ Winning proposals } \\
\hline Total of students & 939 & \multicolumn{2}{l|}{421} \\
\hline Students per group (average) & 4,1 & 4,5 & \\
\hline No. of elements per group & $\begin{array}{l}\text { Proposals } \\
\text { submitted }\end{array}$ & $\%$ & $\begin{array}{l}\text { Proposals } \\
\text { submitted }\end{array}$ & $\%$ \\
\hline 1 & 5 & $2 \%$ & 0 & $0 \%$ \\
\hline 2 & 11 & $5 \%$ & 1 & $1 \%$ \\
\hline 3 & 33 & $14 \%$ & 8 & $9 \%$ \\
\hline 4 & 99 & $43 \%$ & 41 & $44 \%$ \\
\hline 5 & 70 & $31 \%$ & 35 & $37 \%$ \\
\hline 6 & 10 & $4 \%$ & 8 & $9 \%$ \\
\hline 7 & 1 & $0 \%$ & 0 & $0 \%$ \\
\hline 8 & 0 & $0 \%$ & 1 & $1 \%$ \\
\hline Total of proposals & 229 & 100 & 94 & $100 \%$ \\
\hline
\end{tabular}

Analyzing the totals of proposals submitted according to the school year of the respective authors (Figure 1), we realize most of the proposals were developed by students in their 11th year of schooling. This reality is understandable, given that in this school year it is foreseen the implementation of a Case Study within the scope of the 
Geography subject. Moreover, the importance of this implementation is based on the very emergence of Project We Propose!. Even so, it is important to note that we are not talking about an exclusive reality of the 11th Grade which reinforces the versatility of this Project, as well as the appropriateness of the Case Study in this context.

\section{Proposals, by schooling year}

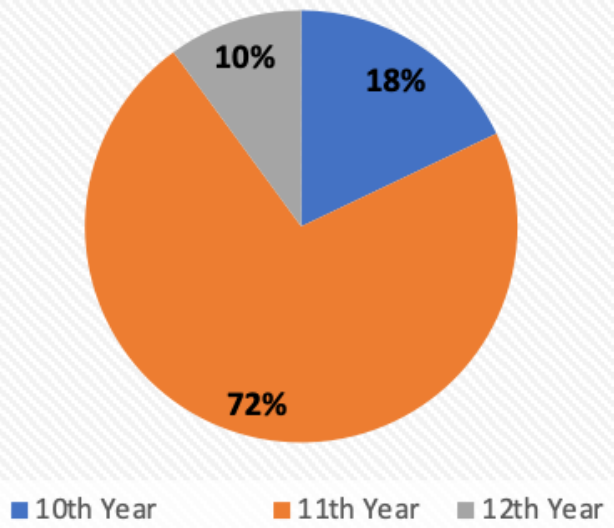

Figure 1. Proposals submitted by schooling year.

\section{Proposals Submitted: Content Analysis}

In order to analyze the types of proposals submitted and their main underlying concerns the proper procedures of content analysis technique were adopted. This choice was motivated by the recognized potential of this type of procedure in terms of handling previously collected information, namely by synthesizing the available information, facilitating its interpretation (Esteves, 2006; Lima, 2013). Given this is a versatile technique, even allowing for the use of specific techniques within the general technique of content analysis (Janeira, 1972), an attempt was made to adapt the proper procedures of this technique to the purposes of this work.

The application of content analysis begins with a phase of "previous analysis" (Bardin, 1977/2004), enabling the initial contact with the information to be analyzed. It is in this first phase that documents to be analyzed are selected. In the case of this text, the analysis focuses on the multimedia presentations related to each proposal submitted by the respective authors. Still in this "previous analysis" phase, there is room for a fluctuating reading (Bardin, 1977/2004), which represents a first general reading of the available information, identifying the first fundamental ideas and opening the way for the following moments, in which the information is organized in more detail. It should be noted that, in the specific case of this analysis, such reading focused on the titles of the proposals submitted by the students.

The conclusions arising from the fluctuating reading leads us to one of the main moments of content analysis. We speak of the categorization of information, which allows for a classification and reduction of data, reconfiguring them to meet the goals of the investigation (Esteves, 2006). This categorization process can take place starting from 
closed procedures, when the categories to be used in the analysis are already defined, or open procedures, when the categories derive from the analyzed information itself (Esteves, 2006). In this work, both procedure types were mobilized. First, there were two general categories defined following a procedure that we can classify as closed. This occurred in order to analyse the content of each proposal submitted at the level of two main dimensions, namely, the main type of concern/problem based on each proposal, as well as the type of the proposal itself, in terms of the actions involved. Two sets of subcategories arise from these two broad categories, seeking to classify more specifically the content of each proposal. In this second moment, a more open procedure was privileged, given that these subcategories were defined during the analysis process according to the characteristics evidenced by the total proposals analyzed throughout this process. We emphasize that, as in any content analysis, the constructed categorization must be a possible approach to the processing of information and not as the only valid categorization for the analysis of such information. After all, "a good categorization, especially if we opted for open procedures, is not the only possible categorization but a defendable categorization" (Esteves, 2006, p. 122). In this analysis, the main goal was to seek a framework for each proposal submitted in the subcategories that would best represent the main underlying concern and the main type of proposal. It is true that in some cases, proposals could fall into more than one subcategory (resulting from each main category). In these situations, for the avoidance of double categorizations, which could compromise the consistency of the analysis carried out, categorization was always sought according to the students' most highlighted aspects, considering the content and the very way they formulated their proposal. Table 3 shows the categories and subcategories resulting from this categorization process.

Table 3

Content Analysis: Categories and Subcategories of Submitted Proposals

\begin{tabular}{|l|l|}
\hline \multirow{4}{*}{ CONCERNS/PROBLEMS } & Environmental \\
\cline { 2 - 2 } & Social and Economic \\
\cline { 2 - 2 } & Cultural/recreation \\
\cline { 2 - 2 } TYPES OF PROPOSALS & Accessibilities/mobility \\
\hline & Intervention in existing building \\
\cline { 2 - 2 } & Intervention in public space \\
\cline { 2 - 2 } & Creation of new infrastructures \\
\cline { 2 - 2 } & Awareness activity \\
\hline & $\begin{array}{l}\text { Activities for assisting the } \\
\text { elderly }\end{array}$ \\
\cline { 2 - 2 } & Change in transport network \\
\cline { 2 - 2 } & Other \\
\hline
\end{tabular}

The versatility associated with content analysis is also manifested in terms of the statistical procedures that can be mobilized for processing information. In the case under analysis, we chose for accounting the frequency of occurrences, that is, assessing how many of the proposals submitted can be classified in each of the categories and subcategories. 


\section{Findings}

\section{Main Concerns of Geography Students, in Different Types of Proposals}

Table 4

Concerns and types of proposals (submission totals)

\begin{tabular}{|l|c|c|c|c|c|}
\cline { 2 - 6 } \multicolumn{1}{l|}{} & \multicolumn{6}{l}{ Types of Concerns at the Base of the Proposals } \\
\hline Types of proposals & Environmental & $\begin{array}{c}\text { Social and } \\
\text { economic }\end{array}$ & $\begin{array}{c}\text { Cultural/ } \\
\text { recreational }\end{array}$ & $\begin{array}{c}\text { Accessibilities/ } \\
\text { mobility }\end{array}$ & TOTALS \\
\hline $\begin{array}{l}\text { Intervention in } \\
\text { existing building }\end{array}$ & 0 & 27 & 37 & 3 & 67 \\
\hline $\begin{array}{l}\text { Intervention in public } \\
\text { space }\end{array}$ & 36 & 20 & 43 & 41 & 140 \\
\hline $\begin{array}{l}\text { Creation of new } \\
\text { infrastructures }\end{array}$ & 7 & 12 & 18 & 4 & 41 \\
\hline Awareness activities & 11 & 4 & 1 & 0 & 16 \\
\hline $\begin{array}{l}\text { Activities for assisting } \\
\text { the elderly }\end{array}$ & 0 & 12 & 0 & 0 & 12 \\
\hline $\begin{array}{l}\text { Change in transport } \\
\text { network }\end{array}$ & 0 & 0 & 0 & 9 & 9 \\
\hline Other & 9 & 21 & 3 & 5 & 38 \\
\hline Totals & 63 & 96 & 102 & 62 & 323 \\
\hline
\end{tabular}

Table 5

Concerns and Types of Proposals (\% Submissions)

\begin{tabular}{|l|l|l|l|l|l|}
\cline { 2 - 6 } \multicolumn{1}{c|}{} & \multicolumn{5}{l}{ Types of Concerns at the Base of the Proposals } \\
\hline Types of proposals & Environmental & $\begin{array}{l}\text { Social and } \\
\text { economic }\end{array}$ & $\begin{array}{l}\text { Cultural/ } \\
\text { recreational }\end{array}$ & $\begin{array}{l}\text { Accessibilities/ } \\
\text { mobility }\end{array}$ & TOTALS \\
\hline $\begin{array}{l}\text { Intervention in existing } \\
\text { building }\end{array}$ & $0 \%$ & $8 \%$ & $11 \%$ & $1 \%$ & $21 \%$ \\
\hline $\begin{array}{l}\text { Intervention in public } \\
\text { space }\end{array}$ & $11 \%$ & $6 \%$ & $13 \%$ & $13 \%$ & $43 \%$ \\
\hline $\begin{array}{l}\text { Creation of new } \\
\text { infrastructures }\end{array}$ & $2 \%$ & $4 \%$ & $6 \%$ & $1 \%$ & $13 \%$ \\
\hline Awareness activities & $3 \%$ & $1 \%$ & $0 \%$ & $0 \%$ & $5 \%$ \\
\hline $\begin{array}{l}\text { Activities for assisting } \\
\text { the elderly }\end{array}$ & $0 \%$ & $4 \%$ & $0 \%$ & $0 \%$ & $4 \%$ \\
\hline $\begin{array}{l}\text { Change in transport } \\
\text { network }\end{array}$ & $0 \%$ & $0 \%$ & $0 \%$ & $3 \%$ & $3 \%$ \\
\hline Other & $3 \%$ & $7 \%$ & $1 \%$ & $2 \%$ & $12 \%$ \\
\hline Totals & $20 \%$ & $30 \%$ & $32 \%$ & $19 \%$ & $100 \%$ \\
\hline
\end{tabular}

Table 4 (total of submitted proposals) and Table 5 (\% of submitted proposals) show the intersection between the subcategories resulting from the two main categories. From the outset, we note that proposals based on cultural and recreational concerns are more frequent, followed by proposals that start from social and economic concerns. As for the types of proposals, we highlight those that involve some type of intervention in the public space, as well as those that involve intervention in an existing building. It should be noted that, even regarding the types of proposals, the verified diversity motivated the creation of subcategory "Other", aiming to gather very different types of proposals, with totals of 
Coscurão, R.; Claudino, S. (2021). Proposals and territorial concerns of the geography students...

occurrences that did not justify the creation of a specific subcategory, but that they couldn't be ignored, obviously.

In this group, we find proposals that range from dredging operations on a river, to the formation of Non-Governmental Organizations, and include the creation of mobile phone applications, among many other examples. Here, we find all the versatility associated with Project We Propose! and the actual execution of the Case Study, allows students to raise different types of social and territorial concerns, in addition to stimulating their creativity and critical spirit as to the type of actions to be proposed in each situation. Moreover, as noted by Souto and Claudino (2019), the problems selected by the students tend to be diverse, resulting from different expectations regarding the use of space, influenced by the respective family and cultural contexts.

Table 6 shows the proportion of each type of proposal, in the context of each type of basic concern. In the case of proposals based on environmental concerns, we found that $57 \%$ of these proposals aimed at some type of intervention in the public space. For example, when faced with the identification of pollution phenomena in their areas of residence, students will frequently propose the installation or reinforcement of equipment in the public space, such as Ecopoints, or cigarette butt collectors. In some cases, this type of concern even leads to propose creating new infrastructures, such as ecological farms and forest biomass plants. Taking into account the nature of these environmental concerns, they provide a bet on activities to raise public awareness. Therefore, it will be surely understood that $17 \%$ of the proposals with environmental concerns are aimed at this type of activities, being directed essentially to raising awareness on the importance of recycling, combating pollution and investing in renewable energies.

Table 6

Types of Proposals, According To the Types of Basic Concerns (\%)

\begin{tabular}{|l|l|l|l|l|}
\cline { 2 - 5 } \multicolumn{1}{c|}{} & \multicolumn{4}{|c|}{ Types of Concerns at the Base of the Proposals } \\
\hline Types of Proposals & Environmental & $\begin{array}{l}\text { Social and } \\
\text { economic }\end{array}$ & $\begin{array}{l}\text { Cultural/ } \\
\text { recreational }\end{array}$ & $\begin{array}{l}\text { Accessibilities/ } \\
\text { mobility }\end{array}$ \\
\hline $\begin{array}{l}\text { Intervention in existing } \\
\text { building }\end{array}$ & $0 \%$ & $28 \%$ & $36 \%$ & $5 \%$ \\
\hline Intervention in public space & $57 \%$ & $21 \%$ & $42 \%$ & $66 \%$ \\
\hline $\begin{array}{l}\text { Creation of new } \\
\text { infrastructures }\end{array}$ & $11 \%$ & $13 \%$ & $18 \%$ & $6 \%$ \\
\hline Awareness activities & $17 \%$ & $4 \%$ & $1 \%$ & $0 \%$ \\
\hline $\begin{array}{l}\text { Activities for assisting the } \\
\text { elderly }\end{array}$ & $0 \%$ & $13 \%$ & $0 \%$ & $0 \%$ \\
\hline Change in transport network & $0 \%$ & $0 \%$ & $0 \%$ & $15 \%$ \\
\hline Other & $14 \%$ & $22 \%$ & $3 \%$ & $8 \%$ \\
\hline Totals & $100 \%$ & $100 \%$ & $100 \%$ & $100 \%$ \\
\hline
\end{tabular}

Regarding social and economic concerns, contrary to what we were able to verify for environmental concerns, we found a more homogeneous distribution of the proposals by different types. Thus, $28 \%$ of these proposals are aimed at interventions in existing buildings, constituting the most frequent situation. We are referring to proposals that aim, 
as a rule, for example, at the rehabilitation of degraded/abandoned buildings; the thinking of creating spaces for assistance to the most vulnerable groups of the population; and university residences, as well as improving the conditions verified in buildings where public services operate. We also highlight the proposals aimed at interventions in public spaces, such as providing the public space with equipment to assist the population including sanitary facilities and public drinking fountains, lamp posts, and thinking about the citizen saftey. It is also important to mention the fact that some proposals have a main concern related to an aging population which helps us to understand that $13 \%$ of the proposals with socio-economic concerns are directed to activities that support the elderly population. The group of proposals falling under the "Other" subcategory also registers a proportion to be noted, in terms of these social and economic concerns. The scope of this type of concern, combined with the afore-mentioned diversity found in this subcategory can help us to understand this result.

As for the proposals whose main concern is of a cultural and recreational nature, we highlight, once again, the examples centered on interventions in public spaces. Proposals aimed at improving public spaces dedicated to the practice of sport and leisure activities are frequent, through the renovation of existing equipment in these spaces. The results are similar when we look at those proposals which are centered on interventions in existing buildings. Many proposals involve, for example, the rehabilitation of dilapidated buildings to create spaces dedicated to tourist activity, or to developing socializing spaces for young people if such a space is absent in the students' area of residence. This reality demonstrates how the proposals are also much linked to their own needs and to the problems and gaps that directly affect the students' daily lives. Also, in this group of proposals, those that provide for the creation of new infrastructures have a similar interventionist situation to those proposed for existing buildings, although the goal is not rehabilitation but rather the construction of new spaces, in places that, in some cases, are already identified by the authors of the proposals.

Given the nature of this type of concern, most of the proposals are based on accessibility and mobility issues and require an intervention in public spaces. We are talking about proposals essentially aimed at improving conditions for the movement of citizens, for example, on public roads, and pedestrian and cycle paths. Likewise, $15 \%$ of the proposals that start with this type of concern are aimed at changing transport networks, a privileged topic within the scope of this type of concerns. Additionally, we should not forget that the transport theme in the context of accessibility and mobility, constitutes one of the syllabus contents of Geography subject in the 11th year of schooling, in Portugal, which will contribute to many proposals targeting this type of issues.

\section{Evaluation of the Project We Propose! By Students}

At the end of the 2019/20 school year, all students who participated in this edition of the Project We Propose! were invited to respond to a final survey, with the aim of evaluating their experience, as students participating in the project. In addition, the responses to this survey show us the general perceptions of students about The Project, which provides us with a set of useful information regarding the impact of this Project on 
the school path of these students, on their lives and on the way they observe their community. There were 166 responses collected in this survey and its main content will be analyzed below.

Regarding the Project's contribution to innovation in education, $86 \%$ of students rate this contribution as good, or very good (Figure 2). This result reinforces the relevance of one of the main bases of this Project: innovation in geographic education.

\section{Innovation in Education}

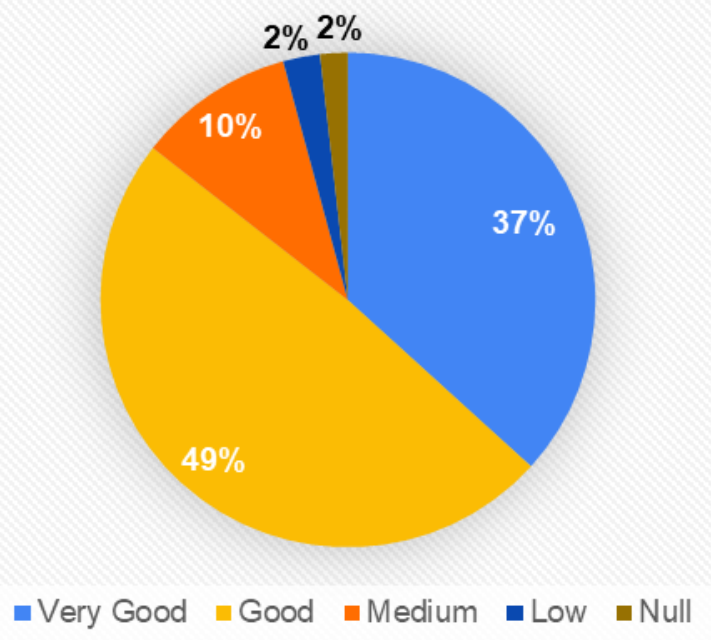

Figure 2. Innovation in geographic education in the context of the Project We Propose!.

Likewise, $82 \%$ of students consider that the motivation for learning is another of the aspects best explored by The Project, and contributes to the enhancement of its pedagogical potential (Figure 3).

\section{Motivation for Learning}

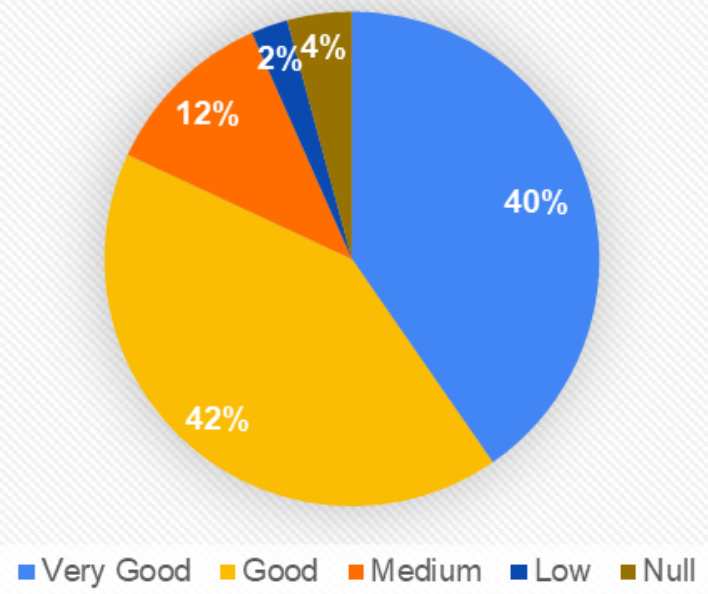

Figure 3. Motivation for learning in the context of the Project We Propose!. 
Working conditions at school are also considered to be good, or very good, by most students (Figure 4). This is another aspect to be taken into account because it is important for the success of the proposals developed by the students within the scope of this Project.

\section{School Working Conditions}

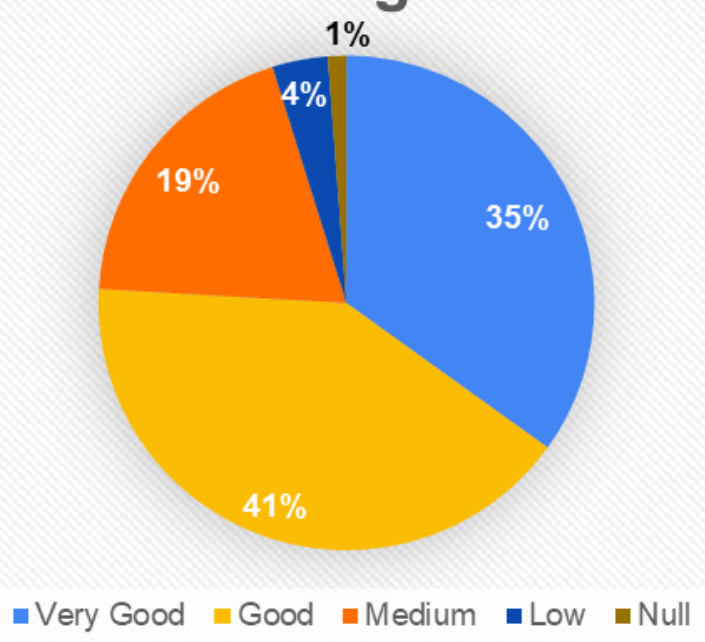

Figure 4. School working conditions in the context of the Project We Propose!.

We are talking about a Project that values group work, which helps us to understand that $81 \%$ of students say cooperation with group colleagues during the development of the work was good, or very good (Figure 5).

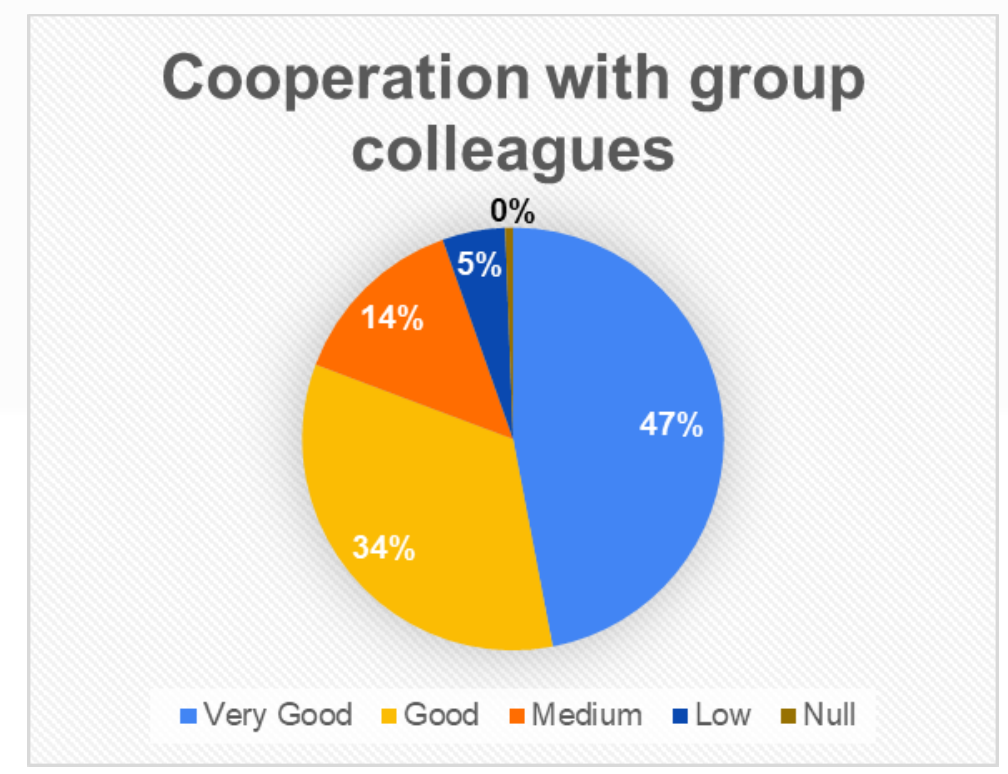

Figure 5. Cooperation with group colleagues in the context of the Project We Propose!.

Without a doubt, Project We Propose! gives significant emphasis to the study of the local scale. More than half of the students consider that The Project's contribution to a better understanding of the local context in which they live was very good (Figure 6). 


\section{Contribution to knowledge of the local context}

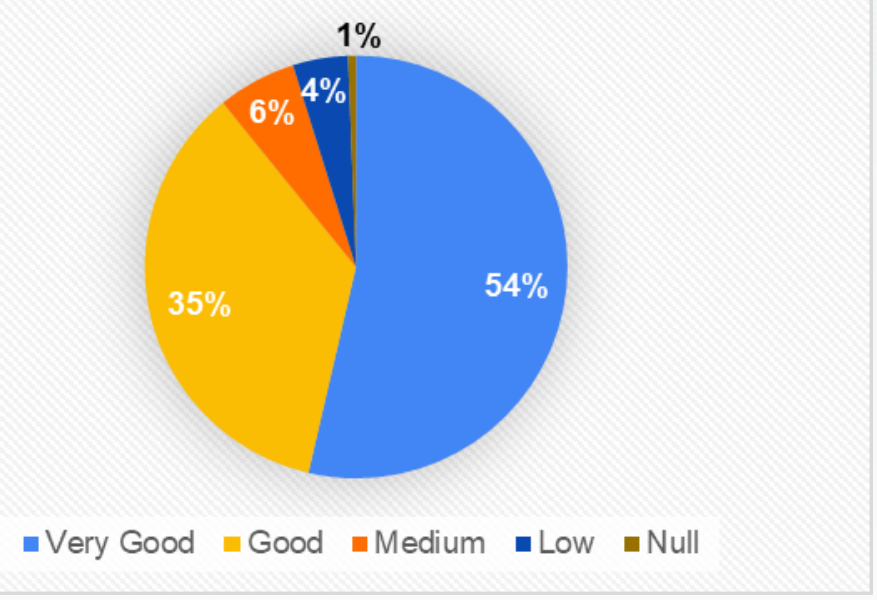

Figure 6. Contribution to knowledge of the local context reflecting on the Project We Propose!.

Still within the scope of the local scale, the reflection and presentation of proposals about local problems was another aspect that brought together more positive results, about the contribution and potential of Project We Propose!. Results indicate that $90 \%$ of students rate this contribution as being good, or very good (Figure 7).

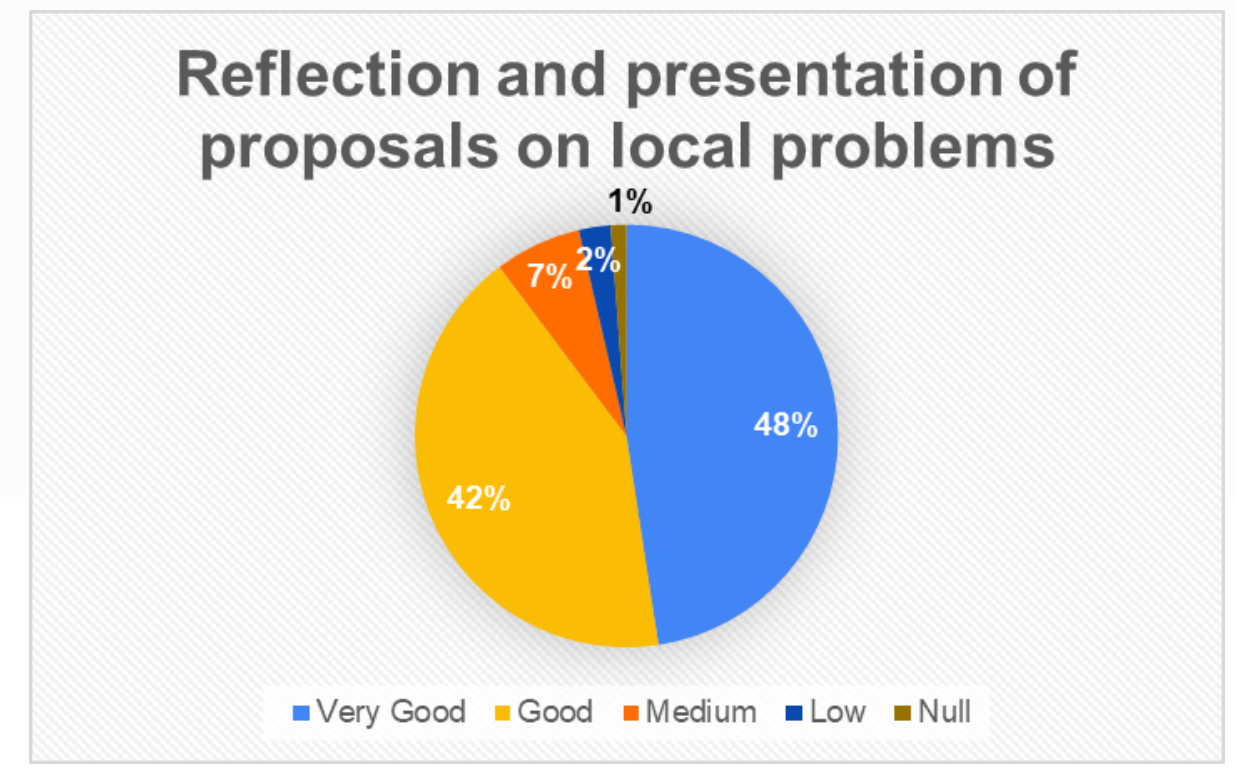

Figure 7. Reflection and presentation of proposals on local problems in the context of the Project We Propose!.

Despite being a work very centered on the students' autonomy, the guidance of the teacher is fundamental for the whole learning process to proceed in the most appropriate way. In the assessment of this monitoring by the students, the results are, once again positive, with the vast majority considering this monitoring as good, or very good (Figure 8). 


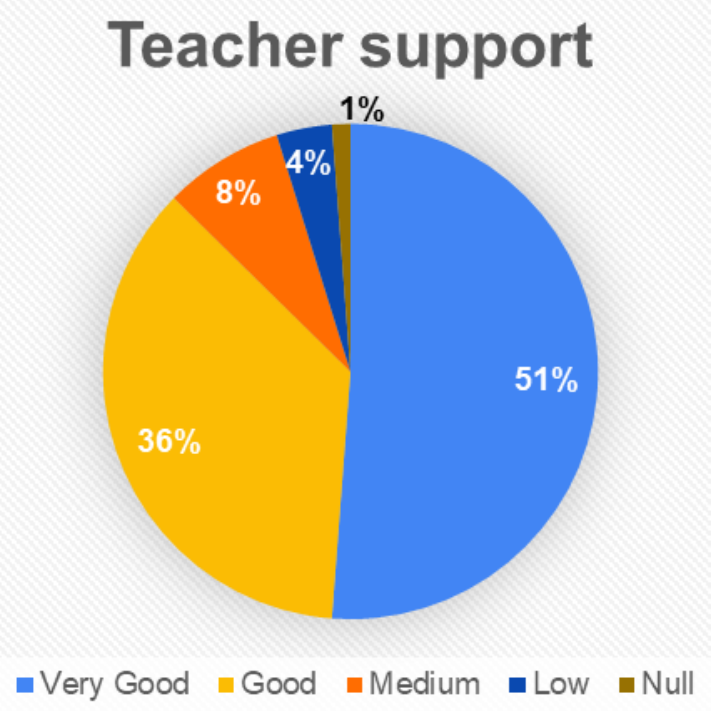

Figure 8. Teacher support in the context of the Project We Propose!.

In a Project of this dimension, coordination and general organization are also fundamental aspects for the success of the entire process. $85 \%$ of students rate this organization as good or very good (Fig. 9), which is very positive feedback about the way the Project is going.

\section{Coordination and general organization of the Project}

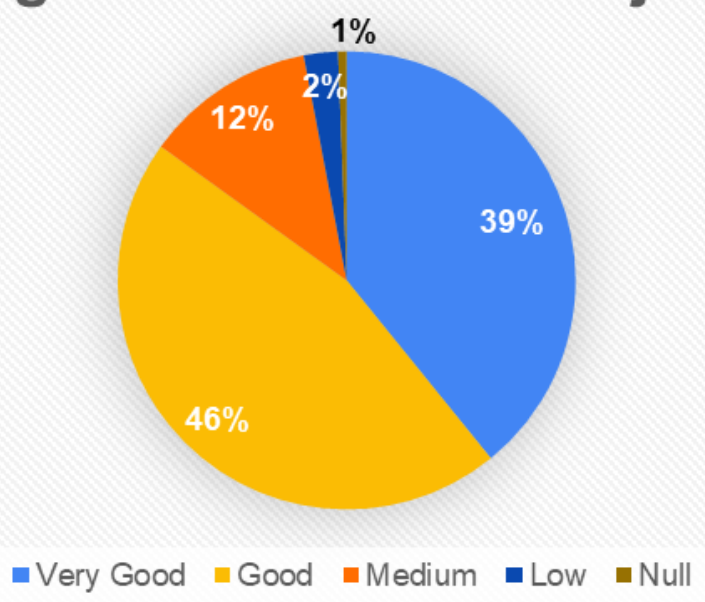

Figure 9. Coordination and general organization of the Project We Propose!.

Increasingly, the use of information technologies plays an important role in the educational context. Project We Propose! is no exception, with $73 \%$ of students reporting they used this type of technology during the course of their work (Figure 10). 


\section{Use of information technologies in the project}

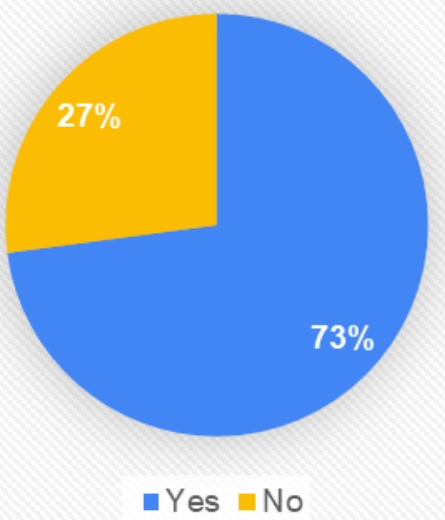

Figure 10. Use of information technologies in the context of the Project We Propose!.

The social impact of Project We Propose! is related, among other aspects, to the dissemination that is carried out outside the school space. The fact students mention to family and friends about their participation in The Project is decisive for the repercussion of this participation and of the broader proposals development. Only less than $10 \%$ of students reported not talking about this Project with family and friends (Figure 11).

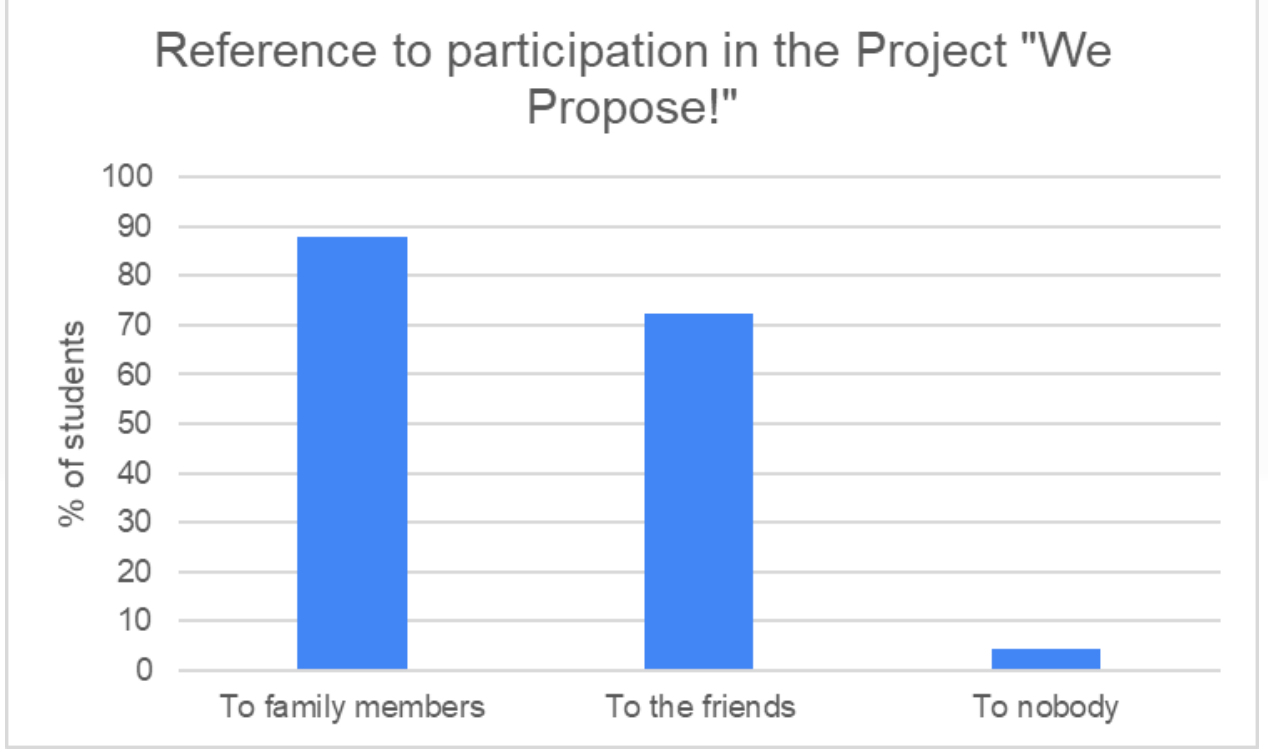

Figure 11. Reference to participation in Project We Propose!, by the students.

Regarding the aspects of most relevance to students within the scope of the Project, the group work and the field work stand out. There are 76,5\% and 63,9\% of students, respectively (Table 7). As we mentioned earlier, these are two inseparable components of the Project We Propose!. 
Table 7

Most relevant aspects of Project We Propose! to students.

\begin{tabular}{|l|c|c|}
\hline \multirow{2}{*}{\multicolumn{2}{|c|}{ Most Relevant Aspects }} & \multicolumn{2}{c|}{ Students } \\
\cline { 2 - 3 } & Total & $\%$ \\
\hline Group work & 127 & 76,5 \\
\hline Fieldwork & 106 & 63,9 \\
\hline Knowing the place of residence better & 105 & 63,3 \\
\hline Promote participatory citizenship & 95 & 57,2 \\
\hline Increased personal competence to participate in & 92 & 55,4 \\
\hline Associate Geography with the planning and spatial & 79 & 47,6 \\
\hline Dissemination of proposals in the community & 77 & 46,4 \\
\hline Increase interest in Geography & 61 & 36,7 \\
\hline Contact local authorities & 49 & 29,5 \\
\hline Support from the local authorities & 28 & 16,9 \\
\hline Acceptance of proposals by the local authorities & 26 & 15,7 \\
\hline
\end{tabular}

The academic year 2019/20 had the peculiarity of coinciding with the beginning of the impacts of the pandemic COVID-19 in all areas of society. In the context of The Project, naturally these impacts were also felt and, once again, we realized the appreciation attributed to fieldwork by students. There were $38.6 \%$ of students who reported the greatest impacts being related to the difficulty in making contact with people and conducting and interviews; and $38.6 \%$ even pointed out the difficulty in developing fieldwork in general (Table 8).

Table 8

Impacts of COVID-19 pandemic on Project We Propose!.

\begin{tabular}{|l|l|l|l|l|l|}
\hline \multicolumn{1}{|c|}{ Impacts of The Covid-19 Pandemic } & $\begin{array}{l}1 \\
\text { (low } \\
\text { impact) }\end{array}$ & 2 & 3 & 4 & $\begin{array}{l}5 \\
\text { (high } \\
\text { impact) }\end{array}$ \\
\hline $\begin{array}{l}\text { Impaired the contact with entities with which it } \\
\text { intended to dialogue/interview }\end{array}$ & 27,1 & 5,4 & 9 & 19,3 & 39,2 \\
\hline Hindered travel to carry out fieldwork & 25,3 & 8,4 & 9 & 18,7 & 38,6 \\
\hline $\begin{array}{l}\text { It was frustrating, as we no longer participated in } \\
\text { the National Seminar at IGOT/University of } \\
\text { Lisbon, as was foreseen }\end{array}$ & 16,9 & 7,2 & 18,7 & 19,9 & 37,3 \\
\hline $\begin{array}{l}\text { It was an important challenge: to demonstrate } \\
\text { how, in a difficult / unforeseen situation, it is } \\
\text { possible to continue and overcome difficulties }\end{array}$ & 7,2 & 6,6 & 23,5 & 34,9 & 27,7 \\
\hline $\begin{array}{l}\text { It was frustrating, as we were no longer publicly } \\
\text { exposing our projects in the community, as was } \\
\text { foreseen }\end{array}$ & 15,1 & 7,2 & 23,5 & 27,1 & 27,1 \\
\hline $\begin{array}{l}\text { It increased tension and uncertainty that affected } \\
\text { the continuation and completion of the Project }\end{array}$ & 30,1 & 12 & 28,3 & 14,5 & 15,1 \\
\hline Hindered group work & 38,6 & 19,3 & 20,5 & 11,4 & 10,2 \\
\hline
\end{tabular}


Coscurão, R.; Claudino, S. (2021). Proposals and territorial concerns of the geography students...

\begin{tabular}{|l|l|l|l|l|l|}
\hline $\begin{array}{l}\text { With the suspension of face-to-face classes, the } \\
\text { We Propose Project! emerged as an even more } \\
\text { important and motivating challenge }\end{array}$ & 25,9 & 18,1 & 33,1 & 15,1 & 7,8 \\
\hline $\begin{array}{l}\text { With the suspension of face-to-face classes, there } \\
\text { was more time to work with the information } \\
\text { already collected and better complete our project. }\end{array}$ & 28,9 & 25,3 & 27,7 & 11,4 & 6,6 \\
\hline Hindered the dialogue/work with the teacher & 50 & 21,1 & 16,3 & 7,2 & 5,4 \\
\hline $\begin{array}{l}\text { It was difficult to contact colleagues and the } \\
\text { teacher, due to telecommunications problems } \\
\text { (internet / computer) }\end{array}$ & 45,8 & 22,3 & 18,7 & 11,4 & 1,8 \\
\hline $\begin{array}{l}\text { With the suspension of face-to-face classes, there } \\
\text { was more time to work on the information already } \\
\text { collected and compete for thematic contests }\end{array}$ & 47 & 17,5 & 27,1 & 6,6 & 1,8 \\
\hline
\end{tabular}

\section{Result and Discussion}

The 2019/2020 edition of Project We Propose! in Portugal occurred during the adverse context of suspended school activities and with students confined at home, however, there was a positive outcome where such resilience demonstrates this is a significant project for many students and teachers.

As for the analysis of the submitted proposals, the realities diversity that can be covered with this type of practice is evident. Four major types of concerns have been identified based on the proposals presented (environmental, social and economic, cultural/recreational and related to accessibility and mobility), with the cultural and recreational concerns being most frequent. Likewise, there were different types of proposals, aimed at interventions and activities of a diversified nature (intervention in an existing building, intervention in the public space, creation of new infrastructures, awareness activities, assistance activities for the elderly, change in transport networks, among others), with emphasis on proposals aimed at interventions in public spaces. This means that in combining both aspects we concluded that proposals involving some type of intervention in the public space were more frequent, based on concerns of a cultural and recreational nature. In the choices made by the students, we also found diverse perceptions, showing a certain proximity to themes that integrate the syllabus set of the Geography subject, not forgetting the personal experience of the students themselves, their needs and the gaps they encounter in the spaces they use in their daily lives.

The school of the 21st Century remains closely linked to the models of the previous centuries: innovation experiences are minor and the discipline of Geography is still closely linked to a nationalist tradition (Pàges I Blanch, 2019). Nevertheless, Project We Propose! demonstrates it is possible to implement, in schools in large urban centers or in more peripheral rural areas, a geographic education in which the youngest work on community problems and in overcoming the well-known "gap" between theoretical discourses and school practice (Massey, 2014). Thus, the local scale is replaced as one that should be privileged in a civically committed Geography (Kenreich, 2019) - bearing in mind that Educating for citizenship means "educating in citizenship" (Figueiredo, 
2005 , p. 23), in belonging to a community, in sharing the way in which its members view common problems, taking decision-making into account. For this very reason, Gracía Pérez (2021), when discussing the difficulties of Geography teachers in implementing citizenship education, proposes, as an alternative to teaching by themes, that to teach about social and environmental problems right from their personal experiences and/or from the investigation of social and environmental problems is necessary (Llancavil Llancavil \& González Quitulef, 2021), as occurs in Project We Propose!

Most of the projects developed by students focus on interventions in public spaces and respond to cultural and recreational problems as well social and economic ones. Increasingly there is an emphasis on environmental and mobility problems which reflecs the evolution of the young people's own interests.

The student proposals result from their critical look at the collective problems affecting the community and from their exercise of constructing proposals for territorial intervention. As such, it points unequivocally to an alternative approach in geographical education for this millennium.

\section{References}

Bardin, L. (2004). Análise de conteúdo. (L. Reto \& A. Pinheiro, Trans.). Lisbon: Edições 70. (Original work published 1977)

Bazolli, J. A. (2017). Nós Propomos! e a busca inovação no campo da extensão universitária. In J. A. Bazolli, S. Claudino, M. V. C Silva, S. F. R. Viana, \& W. C. Silva (Eds.), A extensão universitária como indutora à cidadania: a experiência do "Nós Propomos" (pp. 13-27). Palmas: EDUFT.

Claudino, S. (2015). A educação geográfica em Portugal e os desafios educativos. Giramundo, 2(3), 7-19. http://dx.doi.org/10.33025/grgcp2.v2i3.204

Claudino, S. (2018). Educação geográfica, trabalho de campo e cidadania: o Projeto Nós Propomos!. In F. Veiga (Coord.), O ensino na escola de hoje: teoria, investigação $e$ aplicação (pp. 265-303). Lisbon: Climepsi.

Claudino, S. (2019). Project We Propose! Building territorial citizenship from school. In J. A. Pineda-Alfonso, N. Alba-Fernandez, \& E. Navarro-Medina (Eds.), Handbook of Research on Education for Participative Citizenship and Global Prosperity (pp. 350-382). Hershey: IGI Global.

Esteves, M. (2006). Análise de conteúdo. In J. Lima, \& J. Pacheco (Org.), Fazer investigação: contributos para a elaboração de dissertações e teses (pp. 105-126). Porto: Porto Editora.

Ferreira, M., Alexandre, F., \& Miranda, B. (2001). O ensino da Geografia num contexto de educação para a cidadania. In M. Gaite (Ed.), La formación geográfica de los ciudanos en el cambio de milenio (pp. 155-168). Madrid: Asociación de Geógrafos Españoles.

Figueiredo, C. C. (2005). Formação Cívica. E agora, um tempo para reflectir? In C. Carvalho, F. Sousa, \& J. Pintassilgo (Org.), A educação para a cidadania como dimensão transversal do currículo escolar (pp. 23-47). Porto: Porto Editora.

García Pérez, F. F. (2021). Algunas dificultades del profesorado de Geografía para educar en ciudadanía. Didacticae, 9, 39-52. https://doi.org/10.1344/did.2021.9.39-52 
Coscurão, R.; Claudino, S. (2021). Proposals and territorial concerns of the geography students...

Hilburn, J., \& Maguth, B. (2015). Spatial citizenship education: civic teachers' instructional priorities and approaches. The Journal of Social Studies Research, 39 (2), 107-118. https://doi.org/10.1016/j.jssr.2014.07.001

Ivorra Catalá, E., García Ferrandis, I. \& Moreno Latorre, E. (2020). La participación ciudadana en las agendas 21 locales de la provincia de Valencia. Biblio3W, Revista Bibliográfica de Geografia y Ciencias Sociales, XXV (1305). https://doi.org/10.1344/b3w.25.2020.31518

Janeira, A. (1972). A técnica de análise de conteúdo nas ciências sociais: natureza e aplicações. Análise social, 23, 157-191.

Llancavil Llancavil, D. \& González Quitulef, H. (2021). Pensamiento geografico y educación ciudadana en Chile. Una mirada desde la educación geografica. Didacticae, 9, 25-38. https://doi.org/10.1344/did.2021.9.25-38

Lambert, D. (2017). The relevance of Geography for citizenship education. In L. Leite, L. Dourado, A. Afonso, \& S. Morgado (Eds.), Contextualizing Teaching To Improve Learning The Case Of Science And Geography (pp. 57-71). Hauppauge, NY: Nova Science.

Kenreich, T. W. (2019). Rediscovering the local: collaborative, community maps for civic awareness. In E. Shin, \& S. Bednarz (Eds.), Spatial Citizenship Education. Citizenship through Geography (pp. 72-87). New York and London: Routledge.

Lima, J. (2013). Por uma análise de conteúdo mais fiável. Revista Portuguesa de Pedagogia, 47(1), 7-29. https://doi.org/10.14195/1647-8614_47-1_1

Machon, P., \& Walkington, H. (2000). Citizenship: the role of geography? In A. Kent (Ed.), Reflective Practice In Geography Teaching (pp. 179-191). London: SAGE.

Martins, F. (2017). Teaching to develop geographical thinking. In C. Brooks, G. Butt, \& M. Fargher (Eds.), The power of Geographical Thinking (pp. 199-209). Cham: Springer.

Massey, K. (2014). Global citizenship education in a Secondary Geography course: the students'perspectives. RIGEO, Review of International Geographical Education Online, 4(2), 80-101. Retrieved from http://www.rigeo.org/vol4no2/Number2Summer/RIGEOV4-N2-1.pdf

Pàges I Blanch, J. (2019). Ciudadanía global y enseñanza de las Ciencias Sociales: retos y posibilidades para el futuro. REIDICS, Revista de Investigación en Didática de las Ciencias Sociales, 5, 5-22. https://doi.org/10.17398/2531-0968.05.5

Palacios, F., \& Barahona, S. (2019). Desarrollo del pensamiento geográfico y formación ciudadana: una mirada desde el espacio vivido. Signos Geográficos, 1, 1-18. Retrieved from https://www.revistas.ufg.br/signos/article/view/59376

Schmidt, S. (2011). Making space for the citizen in geographic education. Journal of Geography, 110(3), 107-119. https://doi.org/10.1080/00221341.2011.537671

Shin, E., \& Bednarz, S. (2019). Conceptualizing Spatial Citizenship. In E. Shin \& S. Bednarz (Eds.), Spatial citizenship education. Citizenship through Geography (pp. 1-9). New York and London: Routledge.

Souto, X., \& Claudino, S. (2019). Construímos uma educação geográfica para a cidadania participativa. O caso do projeto Nós Propomos!. Signos Geográficos, 1, 1-16. Retrieved from https://www.revistas.ufg.br/signos/article/view/59171

United Nations. (2015). Transforming our world: The 2030 Agenda for Sustainable Development. Retrieved from https://sdgs.un.org/publications/transforming-our-world-2030-agendasustainable-development-17981

United Nations. (2020). The Sustainable Development Goals Report 2020. Retrieved from https://unstats.un.org/sdgs/report/2020/The-Sustainable-Development-Goals-Report- 
2020.pdf

\section{Biographical Statements}

Ricardo COSCURÃO is currently associated researcher at the Centre of Geographical Studies (CEG). Teacher of Basic and Secondary Education, he has taught in the areas of Geography and Information and Communication Technologies, in diverse contexts, in public education and private education. In addition to teaching and training young people, he has also dedicated to adult education and training. He has collaborated in several activities related to the Project "We Propose! Citizenship and Innovation in Geographic Education ", developed based on IGOTULisboa. Within the scope of his research interests, issues related to Geographic Education and Geography teaching stand out. Since September 2018 he is developing his PhD research, focused on the implementation of the Case Study in the school discipline of Geography, in Secondary Education..

Sérgio CLAUDINO is graduated in Geography, Master in Geography and Regional and Local Planning and $\mathrm{PhD}$ in Human Geography by the University of Lisbon. Professor of Basic and Secondary Education (1981/1986). Assistant Professor of the Institute of Geography and Spatial Planning of the University of Lisbon/IGOT-UL and Full Researcher at the Center for Geographical Studies. The teaching and research activity focuses on teacher training and Geography Teaching. Member of the Board of Directors of the GEOFORO - Iberoamerican Forum on Education, Geography and Society, coordinator of the Master in Geography Teaching at the University of Lisbon, coordinator of the Teacher Training Center of IGOT-UL. He founded and he coordinates the We Propose Project! Citizenship and Innovation in Geographic Education, disseminated at national and international level. 